\title{
О МЕТРОЛОГИИ МЕДНЫХ МОНЕТ САРАЯ, САРАЯ АЛ- ДЖАДИДА И ГУЛИСТАНА В XIV в.
}

\author{
(C) 2020 г. А. И. Бугарчев
}

Целью исследования явилось выяснение номинальной структуры медной монетной системы в Золотой Орде в XIV веке. Рассматрены метрологические характеристики медных ордынских монет. Была изучена продукция монетных дворов Сарай, Сарай ал-Джадида и Гулистан, работавших в разные периоды XIV в. Для исследования использовались сборы с таких городищ и селищ, как Водянское, Селитренное, Царевское, Зубовское, Колобовка и Чертово. Используя результаты в виде гистограмм, автор пришел к выводу, что медные монеты XIV в. чеканились разными весовыми группами, что соответствовало различным номиналам. По мнению автора, в денежном обращении второй половины XIV в. использовались монеты в 1, 11/2, 2, 21/2, $3,3 \frac{1}{2}$ и 4 пула. Они отличались не только весом, но и внешним видом, благодаря чему они легко различались населением.

Ключевые слова: археология, Золотая Орда, Сарай, Сарай ал-Джадида, Гулистан, XIV в., медная монета, пул, комплекс, монетный двор

\section{Введение}

Одним из важнейших источников по изучению истории Улуса Джучидов являются средневековые монеты, выявленные в ходе археологических работ на городищах и селищах. Первым, кто обратил внимание на информационные возможности нумизматических комплексов, был саратовский нумизмат А. А. Кротков. Он писал, что монетные сборы на городищах являются «своего рода кладами, но только принадлежащими не отдельному лицу, а коллективу, тому или иному населенному пункту» [Кротков, 1930, с. 5]. Важность изучения монетных находок с археологических памятников отмечала С. А. Янина: «Каждый единый монетный комплекс того или иного городища, являясь весомым памятником денежного обращения и культу-

ры Золотой Орды, дает возможность решать и конкретные спорные вопросы, связанные с данным городищем» [Янина, 1970, с. 194]. Но основной упор в исследованиях делался на серебряный сбор, поскольку именно на дирхамах, дангах и акче помещались имена эмитентов - правителей государства, а даты и названия монетных дворов указывали на время их правления и подконтрольные им экономически развитые территории.

Вопросам метрологии медных монет нумизматы XIX-XX вв. не придавали значения. Так, при издании монетного комплекса, обнаруженного в 1946-1958 гг. на Болгарском городище, вес приводился только для «серебра» [Янина, 1954; 1958; 1962]. Впервые метрология «меди» была указана при публикации сбора с Ца- 
ревского городища [Янина, 1970]. Тем не менее, и позднее фиксация веса не являлась обязательной. По мнению Г. А. Федорова-Давыдова, медные монеты чеканились «не соблюдая какую-либо строго определенную весовую норму, с очень широким ремедиумом» [Федоров-Давыдов, 1987, с. 180]. При этом некоторые весовые границы весовых норм чеканки медных монет разных правителей все же были обозначены. По расчетам А. Г. Мухамадиева, «пулы Узбека чеканились средним весом около 1,33 г», пулы Джанибека - средним весом 1,95 г, а «медные монеты Хызра чеканились средним весом 3,12 г» [Мухамадиев, 1983, с. 79, 87].

Серьезный анализ комплексов медных монет, собранных на археологических памятниках, впервые провели В. Б. Клоков и В. П. Лебедев. Благодаря их совместной работе, были опубликованы нумизматические комплексы Водянского, Селитренного, Зубовского, Колобовского и Чертого городищ и селищ с приведением веса как серебряных, так и медных монет [Клоков, Лебедев, 2000; 2002; 2004а, 2004б]. К сожалению, нам остались недоступны сведения метрологического характера из последней статьи, поэтому вес монет Царевского городища взят из более ранней работы С. А. Яниной [1970].

\section{Описание материала}

В нашей работе будут использоваться типы и метрология эмиссий монетных дворов (далее-МД) Сарай, Сарай ал-Махруса, Сарай ал-Джадида и Гулистан, выпускавших монеты в XIV в. (За критерий типа принимаются два параметра - композиционное оформление и содержание легенд на каждой из сторон монеты. Изменение одного из параметров даже на одной из сторон монеты означает смену типа монеты [Петров, 2010, с. 126]. Находки медных монет, перечисленных монетных дворов являются самыми частыми в золотоордынских комплексах от дельты Волги на юге до городища Иски-Казань на севере. Более того, в последние годы установилось мнение, что многие не столичные МД в 730-760-х гг.х. выпускали монеты с указанием МД Сарай, Сарай алДжадида и Гулистан (напр. [Клоков, Лебедев, 2000, с. 121; 2002, с. 149]. Весовые характеристики продукции обоих Сараев и Гулистана были приведены В. Б. Клоковым и В. П. Лебедевым при публикациях сборов с вышеуказанных памятников.

Приведем результаты анализов комплексов медных монет в их работах. В статье 2000 г., где рассматривался сбор с Селитренного городища, для выявления метрологических показателей пулов был рассчитан средний вес монет. Для этого авторы использовали суммарную информацию из литературных источников (монография А. Г. Мухамадиева 1983 г., статья С. А. Яниной 1970 г.) и собственные результаты изучения монет Селитренного городища. Исходя из полученной информации, В. Б. Клоков и В. П. Лебедев получили следующие цифры:

- средний вес медных монет Сарая, чеканенных в 726-740 гг.х., равнялся $1,35 \pm 0,05$ г;

- средний вес монет Сарая алДжадида 741-750 гг.х. («двуглавый орел») - 1,15 $\pm 0,05$ г, в статье 2004 г. по материалам гистограммы выявлен максимум на значении $1,30 \pm 0,05$ г [Клоков, Лебедев, 2004, с. 94];

- средний вес монет Сарая алДжадида 751-760 гг.х. («розетка») $2,10 \pm 0,05$ г; 
- средний вес монет с именем Хызра чеканки Сарая ал-Джадида и Гулистана 762 г.х. $-2,8 \pm 0,1$ г [Клоков, Лебедев, 2000, с. 99].

Авторы рассчитали единицу веса, которой кратны вышеуказанные значения. Эта величина в 0,7 г. Таким образом, монеты, чеканенные: в 726740 гг.х., стремились к значению веса в 1,4 г; в 751-760 гг.х. - к значению веса в 2,1 г; 762 г.х. - к значению веса в 2,8 г., а монеты Сарая ал-Джадида 764 г.х. - к значению веса в 4,2 г [Клоков, Лебедев, 2000, с. 99]. Исходя из результатов, к которым пришли В. Б. Клоков и В. П. Лебедев, мы будем называть медные монеты весом 1,4 г пулами, так как только на таких типах помещалась легенда шестнадцать пул - данг.

В отличие от изучения веса серебряных монет, когда основной упор в метрологических расчетах приходится на кладовые комплексы, при исследовании веса медных монет мы опирались на материалы сборов с вышеперечисленных археологических памятников. Используя приложения к статьям 2000, 2002 и 2004 гг, рассмотрим весовое распределение отдельных типов пулов.

Сначала приведем количество учитываемых в расчетах экземпляров медных монет, найденных на следующих городищах.

Таблица 1 - Количество медных монет, найденных на золотоордынских городищах и чеканенных на МД Сарай, Сарай ал-Махруса, Сарай ал-Джадида и Гулистан

Table 1 - Number of copper coins found in the Golden Horde towns and minted at the mints Saray, Saray al-Mahrusa, Saray al-Jadida and Gulistan

\begin{tabular}{|c|c|c|c|c|c|c|c|}
\hline \multirow[t]{2}{*}{$\begin{array}{l}\text { № } \\
\text { типа }\end{array}$} & \multirow[t]{2}{*}{$\begin{array}{c}\text { Год г.х., } \\
\text { эмитент, МД, «тип» }\end{array}$} & 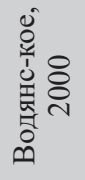 & 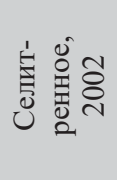 & 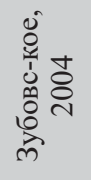 & 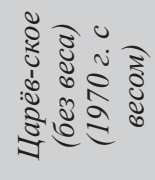 & 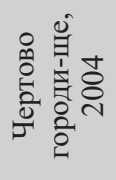 & 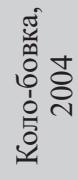 \\
\hline & & \multicolumn{6}{|c|}{ Количество, шт. } \\
\hline 1 & 721, Сарай & 1 & 2 & 48 & 2 & 3 & \\
\hline 2 & 726, Сарай & 15 & 2 & 56 & 4 & 1 & \\
\hline 3 & $\begin{array}{l}731, \\
\text { Сарай ал-Махруса }\end{array}$ & 45 & 17 & 140 & $9(3)$ & 3 & \\
\hline 4 & $\begin{array}{l}\text { «737», Сарай, «лев и } \\
\text { солнце» }\end{array}$ & 101 & 191 & 373 & $12(8)$ & & \\
\hline $4 \mathrm{~A}$ & $\begin{array}{l}737, \text { Сарай, «лев» } \\
\text { вправо и «полное } \\
\text { солнце» }\end{array}$ & 11 & 21 & 81 & 9 & & \\
\hline 5 & $\begin{array}{l}{[743-750]^{1},} \\
\text { Сарай ал-Джадида, } \\
\text { «двуглавый орёл» }\end{array}$ & 273 & 358 & 161 & 789 (130) & 2 & \\
\hline 6 & $\begin{array}{l}{[751-761],} \\
\text { Сарай ал-Джадида, } \\
\text { «розетка» }\end{array}$ & 442 & 284 & 12 & & 57 & 35 \\
\hline
\end{tabular}


Бугарчев А.И. О метрологии медных монет Сарая, Сарая ал-джадида и Гулистана в XIV в.

\begin{tabular}{|c|c|c|c|c|c|c|c|}
\hline \multirow{2}{*}{7} & $\begin{array}{l}\text { 762, Хызр, } \\
\text { Сарай ал-Джадида }\end{array}$ & \multirow{2}{*}{115} & 89 & & $385(28)$ & 5 & 8 \\
\hline & 762, Хызр Гулистан & & & 2 & $524(23)$ & & 10 \\
\hline 8 & $\begin{array}{l}\text { 763, Килдибек, Сарай } \\
\text { ал-Джадида }\end{array}$ & 2 & 56 & & 22 & & \\
\hline 9 & $\begin{array}{l}\text { 764, Гулистан, «зверь } \\
\text { влево» }\end{array}$ & 21 & 12 & & $314(23)$ & & 15 \\
\hline 10 & $\begin{array}{l}\text { 764, Хайр-Пулад, } \\
\text { Сарай ал-Джадида }\end{array}$ & 2 & 84 & & $32(3)$ & 4 & 4 \\
\hline 11 & $\begin{array}{l}\text { 766, Гулистан, } \\
\text { «двуглавый орёл» }\end{array}$ & 3 & 10 & 1 & $243(20)$ & & 16 \\
\hline 12 & $\begin{array}{l}\text { 767, Азиз-Шейх, } \\
\text { Сарай ал-Джадида }\end{array}$ & & 30 & & $16(2)$ & 2 & 7 \\
\hline 13 & $\begin{array}{l}\text { 767, Сарай ал- } \\
\text { Джадида, «АГА», }\end{array}$ & & 30 & & 1 & & 35 \\
\hline 14 & $\begin{array}{l}\text { 767, Гулистан, } \\
\text { «солярный знак» }\end{array}$ & & 4 & & $5(5)$ & & 9 \\
\hline 15 & $\begin{array}{l}\text { 768, Ульджай-Тимур, } \\
\text { Сарай ал-Джадида }\end{array}$ & & 6 & & & & \\
\hline 16 & $\begin{array}{l}768, \\
\text { Сарай ал-Джадида, } \\
\text { 9-ячеистая решётка, }\end{array}$ & & 7 & & & & 1 \\
\hline 17 & $\begin{array}{l}\text { 768, Сарай ал- } \\
\text { Джадида, «зверь } \\
\text { влево или вправо» }\end{array}$ & & 41 & & 1 & 17 & \\
\hline 18 & $\begin{array}{l}\text { «768», } \\
\text { Сарай ал-Джадида, } \\
\text { 4-осный орнамент, }\end{array}$ & & 35 & & 2 & 12 & 1 \\
\hline 19 & $\begin{array}{l}\text { 773, Тулунбек хатун, } \\
\text { Сарай ал-Джадида }\end{array}$ & & 61 & & & 27 & \\
\hline 20 & 787, Сарай, «секира» & & 70 & & & & \\
\hline 21 & $\begin{array}{l}\text { 7902 }, \text { ac-Сарай, } \\
\text { 5-лепестковый орн., }\end{array}$ & 8 & 90 & & (1) & & \\
\hline 22 & $\begin{array}{l}\text { 790-791, } \\
\text { Сарай ал-Джадида, } \\
\text { 6-угольная звезда }\end{array}$ & & $67+5$ & & 1 & & 1 \\
\hline 23 & $\begin{array}{l}\text { 796, Сарай ал- } \\
\text { Джадида, } \\
\text { «две птицы» }\end{array}$ & 3 & 36 & & & & \\
\hline
\end{tabular}

Исходя из представленной информации, нами были построены гистограммы зависимости количества монет от значений их веса (см. при- ложение). Для отдельных типов с небольшим количеством известных экземпляров пришлось суммировать весовые данные из нескольких 
источников. Это сделано для «меди» Гулистана 764, 766 и 767 гг.х. и Сарая ал-Джадида 767 и 768 гг.х. Результа- ты гистограмм представлены в таблице 2. Изображения типов медных монет приведены на рисунках 1 и 2.

Таблица 2 - Моды отдельных типов медных монет по результатам построения зависимости количества монет от их значения веса

Table 2 - Modes of individual types of copper coins based on the results of the construction of the dependence of the number of coins on their weight value

\begin{tabular}{|c|c|c|c|c|c|c|c|}
\hline \multirow[b]{2}{*}{$\begin{array}{l}\text { № } \\
\text { типа }\end{array}$} & \multirow[b]{2}{*}{$\begin{array}{c}\text { Год г.х., эмитент, } \\
\text { МД, тип }\end{array}$} & \multicolumn{5}{|c|}{ Мода, г } & \multirow[b]{2}{*}{ Примечание } \\
\hline & & 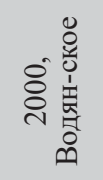 & 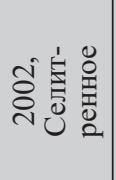 & 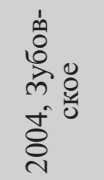 & 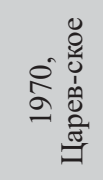 & 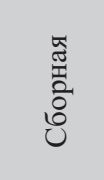 & \\
\hline 1 & 721, Сарай & & & $1,3 \pm 0,1$ & & & Мода $(1,4 \pm 0,1)$ \\
\hline 2 & 726, Сарай & & & $1,4 \pm 0,1$ & & & Мода $(1,4 \pm 0,1)$ \\
\hline 3 & 731, Сарай & $1,3 \pm 0,1$ & & $1,3 \pm 0,1$ & & & $\begin{array}{l}\text { Показатели } \\
\text { клада пулов } \\
731 \text { г.х. - мода } \\
(1,4 \pm 0,1)^{1}\end{array}$ \\
\hline 4 & $\begin{array}{l}\text { (737-743), Сарай, } \\
\text { «лев-солнце» }\end{array}$ & $1,2 \pm 0,1$ & $1,3 \pm 0,1$ & $1,2 \pm 0,1$ & $1,1 \pm 0,1$ & & 564 экз. \\
\hline $4 \mathrm{~A}$ & $\begin{array}{l}\text { 737, Сарай, } \\
\text { «лев и полное } \\
\text { солнце» }\end{array}$ & & & $1,4 \pm 0,1$ & & & 81 экз. \\
\hline 5 & $\begin{array}{l}\text { (743-750), САД, } \\
\text { «двуглавый орел» }\end{array}$ & $1,4 \pm 0,1$ & $1,3 \pm 0,1$ & $1,2 \pm 0,1$ & & & $\begin{array}{l}519 \text { экз. } \\
\text { Гист. } 1 .\end{array}$ \\
\hline 6 & $\begin{array}{l}\text { (751-760), САД, } \\
\text { «розетка» }\end{array}$ & $2,0 \pm 0,1$ & $2,2 \pm 0,1$ & & & & $\begin{array}{l}726 \text { экз. } \\
\text { Гист. } 2 .\end{array}$ \\
\hline 7 & $\begin{array}{l}\text { 762, Хызр, } \\
\text { САД и Гулистан }\end{array}$ & $2,9 \pm 0,1$ & $3,1 \pm 0,1$ & & $2,5 \pm 0,1$ & & $\begin{array}{l}101 \text { экз. } \\
\text { Гист. } 3 .\end{array}$ \\
\hline 8 & $\begin{array}{l}\text { 763, Килдибек, } \\
\text { САД }\end{array}$ & & $2,2 \pm 0,1$ & & & & $\begin{array}{l}56 \text { экз. } \\
\text { Для д. } \\
\text { Сахаровка - } \\
(2,1 \pm 0,1)^{2}\end{array}$ \\
\hline 9 & $\begin{array}{l}\text { 764, Гулистан, } \\
\text { «зверь» }\end{array}$ & $4,5 \pm 0,1$ & & & $4,6 \pm 0,1$ & $4,4 \pm 0,1$ & $\begin{array}{l}88^{3} \text { экз. } \\
\mathrm{B}_{\text {ср. }} \text { без крайних } \\
\text { значений } \\
=4,2 \text { г. }\end{array}$ \\
\hline 10 & $\begin{array}{l}\text { 764, Хайр-Пулад, } \\
\text { САД }\end{array}$ & & $2,6 \pm 0,1$ & & & & 84 экз. \\
\hline 11 & $\begin{array}{l}\text { 766, Гулистан, } \\
\text { «двуглавый орел» }\end{array}$ & & & & & $2,5 \pm 0,1$ & $\begin{array}{l}63^{4} \text { экз. } \\
\mathrm{B}_{\text {cp. }}=2,5 \text { г. }\end{array}$ \\
\hline 12 & $\begin{array}{l}\text { 767, Азиз-Шейх, } \\
\text { САД }\end{array}$ & & $2,3 \pm 0,1$ & & & $2,4 \pm 0,1$ & $\begin{array}{l}54^{5} \text { экз. } \\
\mathrm{B}_{\text {cp. }}=2,5 \text { г. }\end{array}$ \\
\hline 13 & $\begin{array}{l}\text { 767, САД, } \\
\text { «АГА» }\end{array}$ & & & & & $2,2 \pm 0,1$ & $\begin{array}{l}40^{6} \text { экз. } \\
\mathrm{B}_{\text {сp. }} \text { без крайних } \\
\text { значений }= \\
2,3 \text { г }\end{array}$ \\
\hline 14 & $\begin{array}{l}\text { 767, Гулистан, } \\
\text { «свастика» }\end{array}$ & & & & & $3,9 \pm 0,1$ & $\begin{array}{l}19^{7} \text { экз. } \\
\mathrm{B}_{\text {cp. }}=3,9 \text { г. }\end{array}$ \\
\hline
\end{tabular}


Бугарчев А.И. О метрологии медных монет Сарая, Сарая ал-джадида и Гулистана в XIV в.

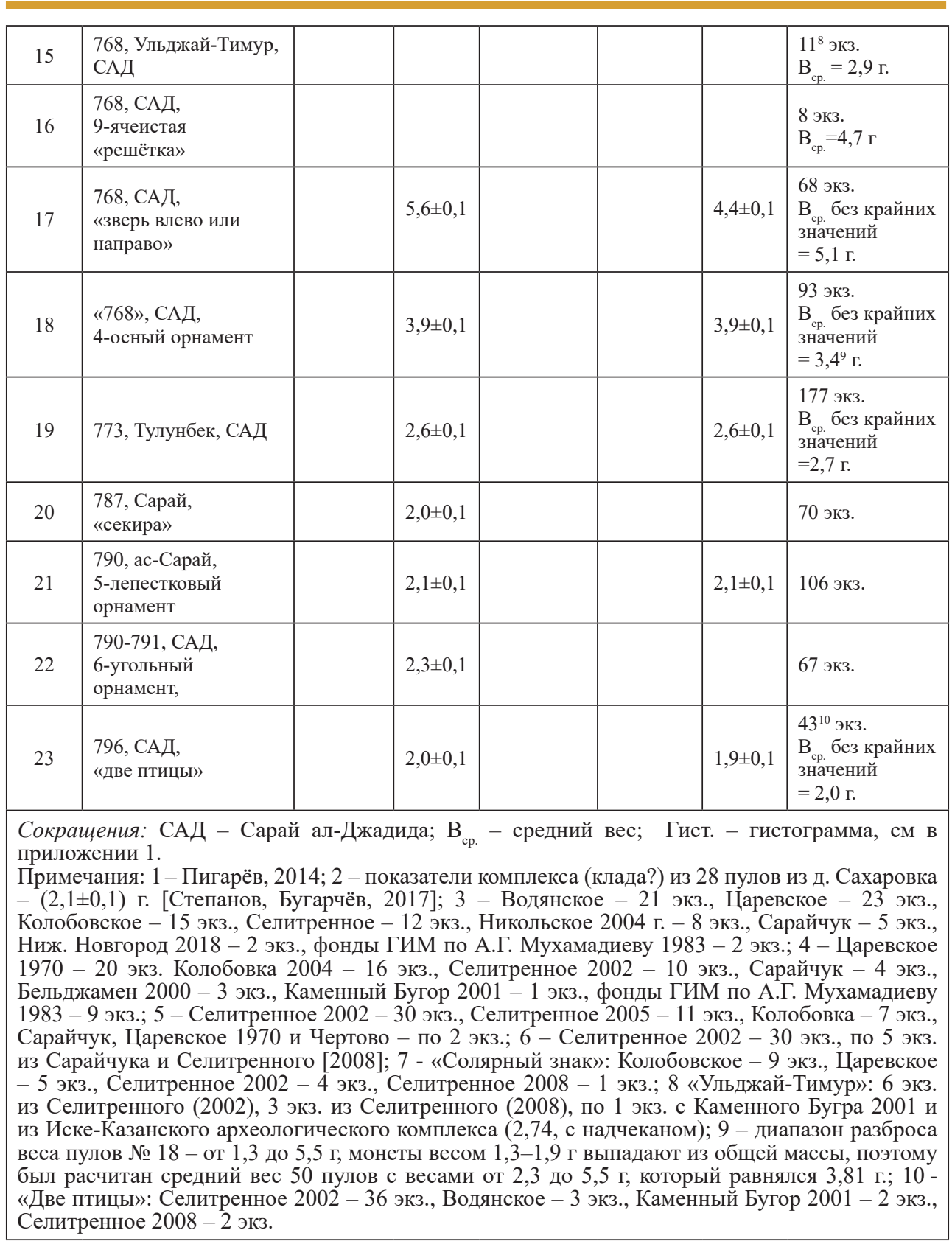

Мы не имеем возможности привести все построенные нами гистограммы, поэтому для образца приводятся только три графика (см. приложение 1), упомянутых в примечании таблицы 2. Из анализа таблицы 2 следует, что в период 721-750 гг.х. пулы чеканились с весовым ориентиром на
1,4 г на МД: Сарай в 721-743 гг.х., Сарай ал-Джадида - в 743-750 гг.х. (рис. 1, 1-5). Позднее, в 751-760 гг.х. на МД Сарай ал-Джадида стали чеканиться полуторные пулы "розетка» с весом 2,1 г, то есть в полтора раза тяжелее пулов предыдущего времени (рис. 1,6). 

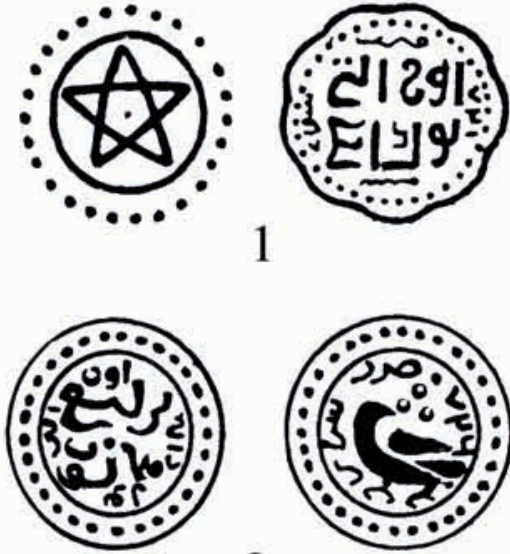

2
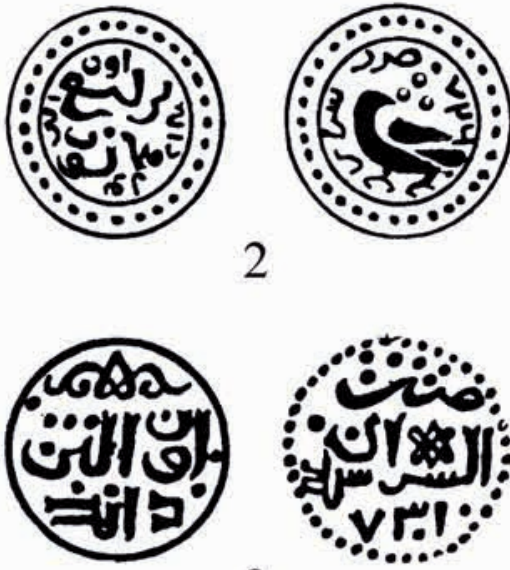

3
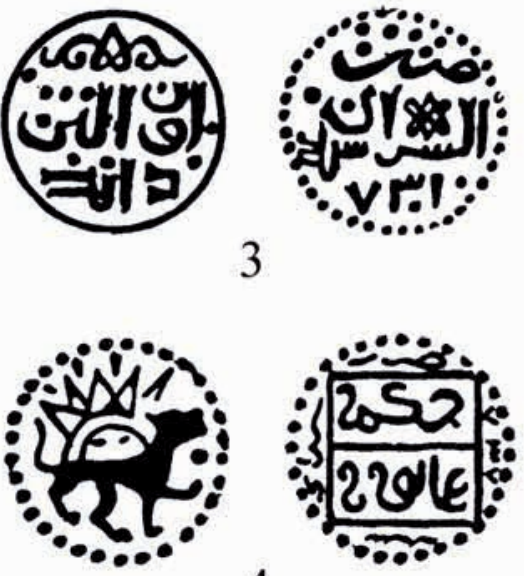

4

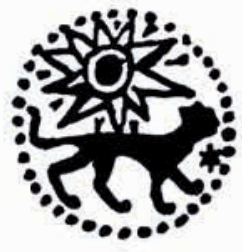

$4 \mathrm{a}$

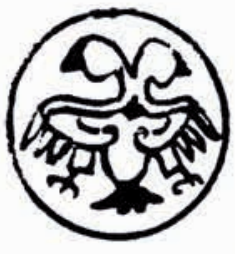

5
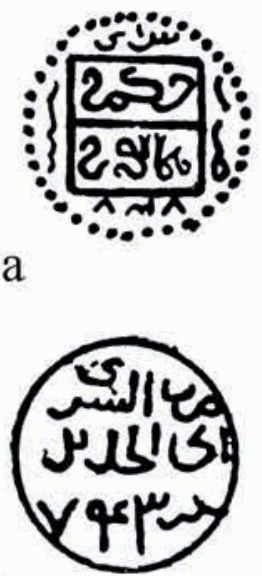

5

Pис. 1. Типь медных монет 721-764 г2.х.

Fig. 1. Copper coins types of 721-764

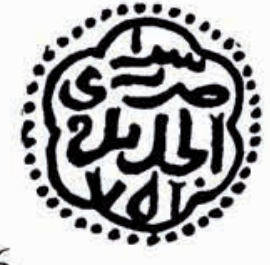

6

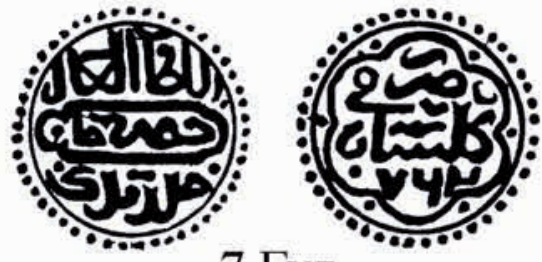

7 Гул.
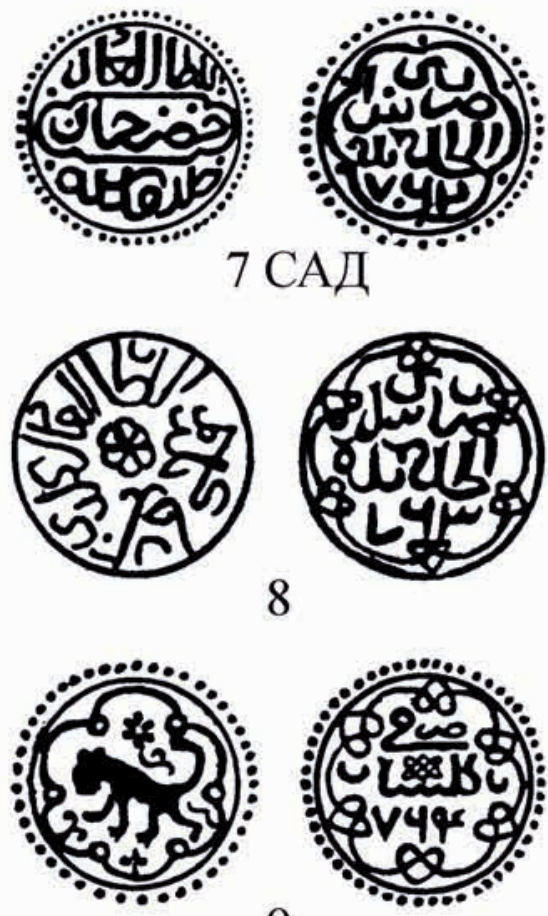

9
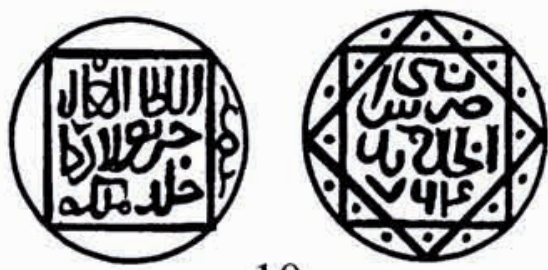

10 


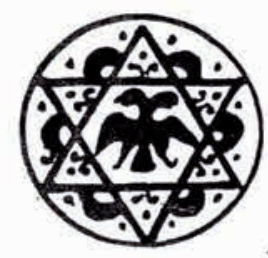

11
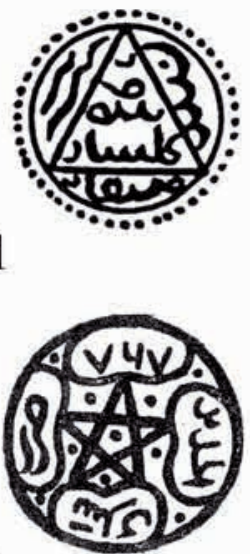

12

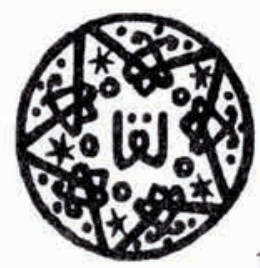

13
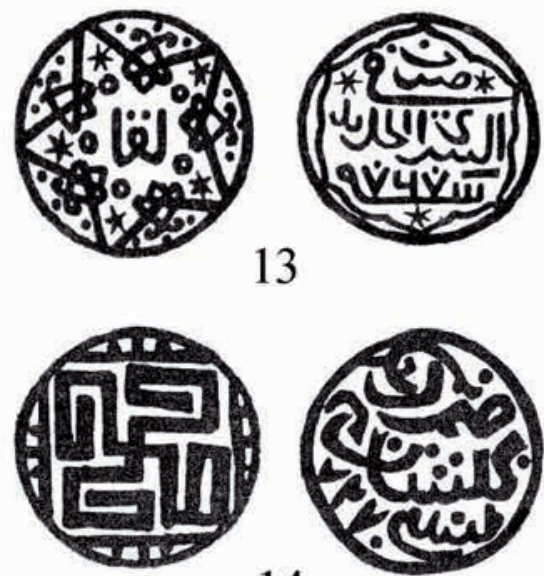

14
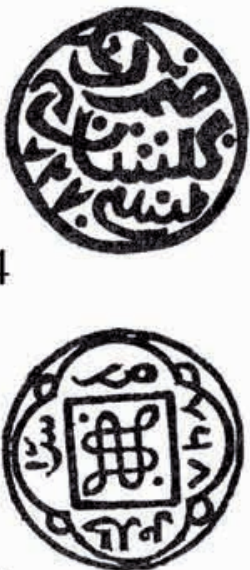

15

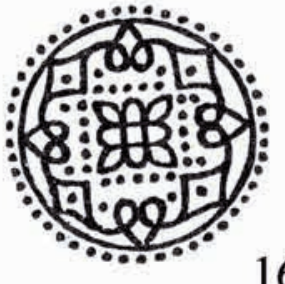

16
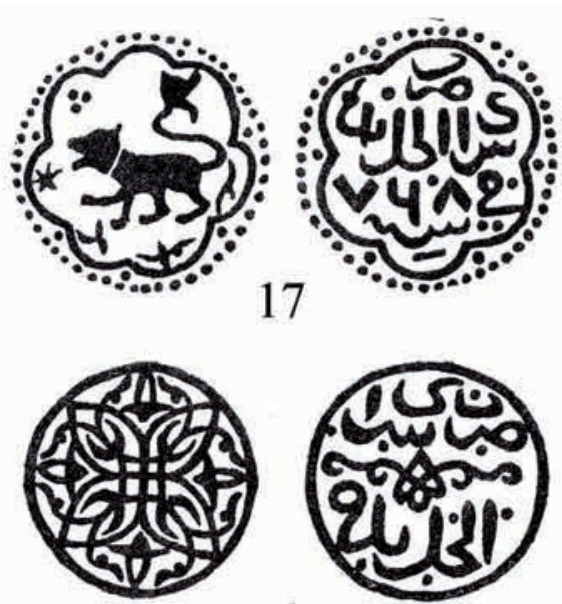

18
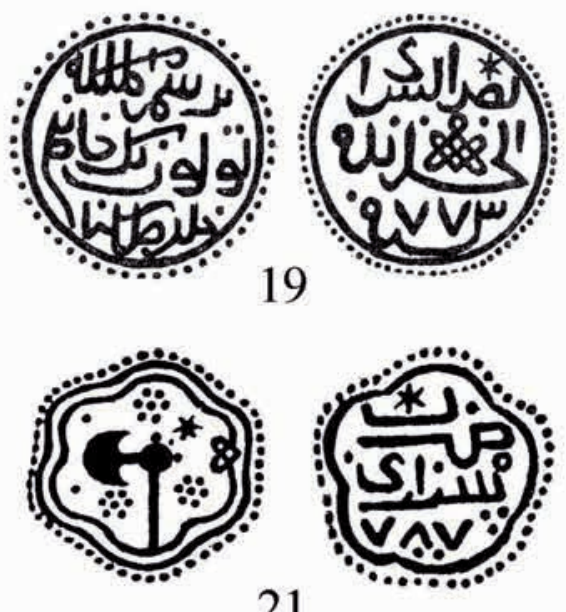

21
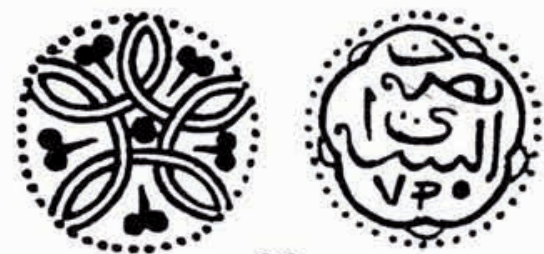

22
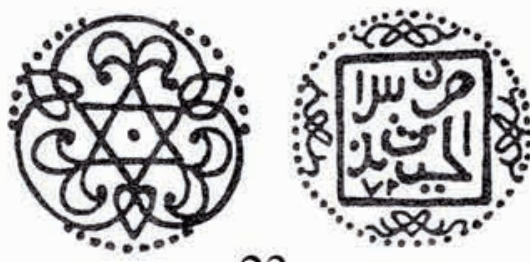

23

Pис. 2. Типь медных монет 766-790 г.х.

Fig. 2. Copper coins types of 766-790 
Прорисовки монет, использованные в рисунках 1 и 2, взяты из разных, упомянутых здесь, статей В. Б. Клокова и В. П. Лебедева.

\section{Обсуждение}

В 762 г.х. начал работать новый монетный двор - Гулистан. Единственный раз внешний вид монет Сарай ал-Джадида и Гулистан был идентичен - на них помещалось имя хана - Хызра, оформление поля на лицевой стороне также было одинаковым, различие проявлялось только на оборотных сторонах - в проставленном названии монетного двора (рис. 1, 7). Монеты чеканились с фактическим весом 2,9-3,1 г. Судя по большому количеству находимых экземпляров, двойные пулы с именем Хызра, помеченные топонимами Сарай ал-Джадида и Гулистан, чеканились на многих монетных дворах государства в течение нескольких лет. Например, на Болгарском городище за период 1946-1958 гг. было обнаружено 293 подобные монеты [Янина, 1962, с. 164-165]* (*В тексте на с. 159 указано количество 6 экз., в сводной таблице на с. 165 указано количество 8 экз. Хызра МД Сарай алДжадида. Нами учтено 6 экз. - прим. авт.). Нельзя исключать возможность, что сам монетный двор Гулистан выпускал пулы с именем Хызр-хана вплоть до 766 г.х. включительно. На каждом крупном археологическом памятнике среди сотен «хызровских» медяков встречаются монеты с датой «766» (например, на Болгарском городище в 1946-1952 гг. обнаружено 17 монет с указанной датой [Янина, 1954, c. 444]).

В 763 г.х. на МД Сарай алДжадида был выпущен новый тип с именем Килдибека и с весом 2,1-2,2 г. Как версию можно предположить, что полуторные пулы «розетка» весом 2,1 г могли чеканиться до 763 г.х., то есть параллельно с двойными пулами Хызра, пока их не сменили монеты с именем Килдибека аналогичной весовой группы (рис. 1, 8).

В 764 г.х. появились новые типы - на монетном дворе Сарай алДжадида стали чеканиться монеты с именем Хайр-Пулада весом 2,6 г, а Гулистан стал производить пулы весом 4,4-4,5 г, или в полтора раза тяжелее хызровских пулов и в два раза тяжелее полуторных по весу пулов 1350-х гг. с «розеткой» (рис. 1, 9, 10).

В 766 г.х. был выпущен тип МД Гулистан с весом 2,5 г (рис. 2, 11).

Позднее, в 767 г.х., монетное производство Сарай ал-Джадида выпустило два новых типа (с именем Азиз-Шейха и так называемый тип «АГА») с одинаковым весом - 2,22,3 г, а Гулистан - более тяжелые монеты «солярный знак» средним весом 3,9 г и возможным номиналом в 3 пула (рис. 2, 12-14).

Эмиссии Гулистана с годами после 767 г.х. не известны, в то время как производство Сарай ал-Джадида продолжало функционировать и в 768 г.х. были выпущены четыре типа пулов:

- с именем Ульджай-Тимура, мода 2,5 $\pm 0,1$ г (средний вес 11 экз. 2,9 г) (рис. 2, 15);

- с «4-осным» орнаментом, мода $3,9 \pm 0,1$ г (как у гулистановских пулов с «солярным знаком») (рис. 2, 18);

- с орнаментом - 9-ячеистой решеткой, средний вес 8 экз. 4,7 г (рис. 2, 16);

- с изображением зверя, идущего вправо или влево, мода 5,6 $\pm 0,1$ г (рис. 2, 17);

Как видно из приведенных цифр, в 768 г.х. на монетном дворе Са- 
рай ал-Джадида было выпущено четыре серии разнотипных и разновесных монет. После выпусков 768 г.х. следует перерыв в чеканке меди с указанием года выпуска. В следующем десятилетии Сарай ал-Джадида начал выпускать монеты в 773 г.х. с именем Тулунбек-ханум и весовой ориентацией на 2,6 г, то есть в весовом отношении соотвествовала монетам Хайр-Пулада (рис. 2, 19). В этот период возобновило работу монетное производство Сарай (ас-Сарай).

При Токтамыше в 787 г.х. монеты Сарая выпускались с фактической весовой ориентацией на 1,8 г, а через 3 года (в 790 г.х.) - на 2,1 г. В следующем 791 г.х. на МД Сарай ал-Джадида чеканились монеты с весовой ориентацией на 2,3 г (рис. 2, 21-23).

Мы специально выделили строчку в таблицах 1 и 2 для типа «лев - полное солнце», поскольку, судя по опубликованным материалам, данные пулы чеканились в одном месте, и, в отличие от пулов «лев и солнце», не имели такого большого количества штемпельных вариантов [Клоков, Лебедев, 2000, с. 125, рис. 3, № 13]. Исходя из этого, можно полагать, что мода в 1,4 г для монет типа «лев - полное солнце» является наиболее близкой к изначальной моде, которую демонстрировали только что отчеканенные монеты.

Если взять за основу расчетов установленную В. Б. Клоковым и В. П. Лебедевым минимальную величину веса в 0,7 г и представить ее в качестве единицы отсчета для анализа полученных нами модальных величин, то эти выявленные моды будут являться кратными избранной единице. Таким образом, все разновесные «медяки» фактически составляют систему медных номиналов монет. В виде таблицы это выглядит следующим образом (см. табл. 3).

Таблица 3 - Соотношение веса медных монет XIV в.

Table 3 - Weight ratio of copper coins of XIV century

\begin{tabular}{|c|c|c|c|c|c|c|c|}
\hline \multirow[b]{2}{*}{ № типа, год х. } & \multicolumn{7}{|c|}{ Весовая группа (номинал) } \\
\hline & $\begin{array}{c}1 \\
1,4 \text { г }\end{array}$ & $\begin{array}{c}1+1 / 2 \\
2,1 \Gamma\end{array}$ & $\begin{array}{c}2 \\
2,8 \Gamma\end{array}$ & $\begin{array}{c}2+1 / 2 \\
3,5 \Gamma\end{array}$ & $\begin{array}{c}3 \\
4,2 \text { г }\end{array}$ & $\begin{array}{c}3+1 / 2 \\
4,9 \text { г }\end{array}$ & $\begin{array}{c}4 \\
5,6 \text { г }\end{array}$ \\
\hline $1-5.721-750$ & $\mathrm{X}$ & & & & & & \\
\hline 6. 751-760 & & $\mathrm{X}$ & & & & & \\
\hline 7. 762 & & & $\mathrm{X}$ ? & $\mathrm{X}$ ? & & & \\
\hline 8.763 & & & $\mathrm{X}$ & & & & \\
\hline 9. $764 *$ & & & & & & $\mathrm{X}$ & \\
\hline $\begin{array}{l}\text { 10. } 764 \text { (Хайр- } \\
\text { Пулад)* }\end{array}$ & & & & $\mathrm{X}$ & & & \\
\hline 11.766 & & & $\mathrm{X}$ ? & & & & \\
\hline $\begin{array}{l}\text { 12-13. } 767 \\
\text { (Сарай ал-Джадида) }\end{array}$ & & $\mathrm{X}$ & & & & & \\
\hline 14. 767 (Гулистан) & & & & & $\mathrm{X}$ & & \\
\hline $\begin{array}{l}\text { 17. } 768 * \\
\text { «зверь влево или } \\
\text { направо» }\end{array}$ & & & & & & & $X$ \\
\hline
\end{tabular}




\begin{tabular}{|c|c|c|c|}
\hline 18. «768»*, орнамент & & & $\mathrm{X} ?$ \\
\hline 19.773 & & $\mathrm{X}$ & \\
\hline 20.787 & $\mathrm{X}$ & & \\
\hline 21.790 & $\mathrm{X}$ & & \\
\hline 22.791 & $\mathrm{X} ?$ & & \\
\hline 23.796 & $\mathrm{X}$ & & \\
\hline \multicolumn{4}{|c|}{$\begin{array}{l}\text { Примечание: *Последовательность типов 9-10 (764 г.х.) и типов 17-18 (768 гг.х.) поставлена } \\
\text { произвольно. В отдельных случаях у нас не было возможности однозначно установить, к } \\
\text { какой весовой группе относятся монеты данного типа. В таких случаях в таблице поставлен } \\
\text { вопросительный знак. }\end{array}$} \\
\hline
\end{tabular}

В таблице 3 не представлены монеты 768 г.х. Сарая ал-Джадида, тип «9-ячеистая решетка» и «УльджайТимур», № 15-16, из-за небольшого количества известных нам экземпляров (средний вес 4,7 г и 2,9 г, соответственно, что может приравниваться к номиналам в $3 \frac{1}{2}$ и 2 пула). Из таблицы 3 следует, что с 721 до $\sim 750$ г.х. выпускались пулы с пятиконечной звездой (721 г.х.), с изображением сокола (726 г.х.), с легендой ун алты (пул) данг (731 г.х.), с изображением «льва и солнца» (с 737 г.х.) и с изображением «двуглавого орла» (с 743 г.х.). Все они чеканились как один номинал, а типы сменяли один другой вследствие развития инфляционных процессов из-за неконтролируемых объемов выпуска пулов. Начиная с 751 г.х., стали чеканиться пулы полуторного номинала («розетка»).

В 760-770-х гг.х. отдельные типы с изменением визуального оформления выпускались в прежних весовых границах: тип 764 г.х. (с именем Хайр-Пулада) - 21/2 пула, типы 767 г.х. (с именемАзиз-Шейха и «АГА») - 11/2 пула, тип 773 г.х. (с именем Тулунбек) - 2 пула. Самые «тяжелые» монеты чеканились в 768 г.х. номиналом в 4 пула. В 780-790-х гг.х. (в конце XIV в.) на МД Сарай и Сарай ал-Джадида также чеканились двойные пулы.

В своей статье 1966 г. Елена Абрамовна Давыдович вывела три критерия различия медных номиналов: «Медные монеты разного достоинства различались размерами, часто - внешним видом и обязательно - соответственно кратным весом» [Давыдович, 1966, с. 127]. Как мы видим, на ордынских монетах XIV в. два выведенных критерия - вес и внешний вид - полностью подтверждаются.

Тот факт, что медные монеты разных номиналов разных годов выпуска обращались вместе, подтверждается опубликованными кладами медных монет. Укажем на некоторые из них:

- клад весом 6 фунтов (около 2,4 кг) медных джучидских монет, г. Царицын, 1890-1892 [Федоров-Давыдов, 1960, № 325]. В кладе присутствовали монеты Хызра 761 г.Х., МД Сарай ал-Джадида и Гулистана и монеты со зверем 764 г.х., МД Гулистан;

- клад из 53 монет с Селитренного городища, 1977 г. [Федоров-Давыдов, 2003, № 325 д]. Состоял из пулов, чеканенных при Токтамыше: с двумя рыбами (тип «Янина, 1954, № 141»), с «весами» (тип «Янина, 1954, № 130») и др.;

- клад с Селитренного городища 1986 г. [Федоров-Давыдов, 2003, № 325 л]. Состоял из монет Гулистана 764 г.х. (тип «Янина, 1954, № 112»), Сарая и Сарая ал-Джадида (там же, «№ 123 и 133»; тип «Янина, 1958, № 121 а») и др.;

- клад с Водянского городища 1973 г. [Федоров-Давыдов, 2003, № 328 г]. В кладе находились монеты с «розеткой» 1350-х гг., МД Гулистан 764 г.х. и с именем Хызра 762 г.х.

Определенную роль в обращении медных монет играли надчеканы, появившиеся во второй половине 1360-х гг. Известно, что в Булгаре использовались «лировидная тамга» и другие графические формы, на Водянском городище - 
адил и другие, на Маджаре - стилизованная цифра «5», круг со «спицами» и т.д.

\section{Bblвodbl}

Проведенное исследование позволило отследить динамику «медного» монетного дела. По мнению Г. А. ФедороваДавыдова, «с 1310 по 1380 гг. средние веса пулов отдельных выпусков изменялись, имея тенденцию в медных эмиссиях Сарая, Сарая ал-Джедид и Гюлистана к повышению. Так, например, сравнительно легкие пулы 1330 г. сменились более тяжелыми в среднем пулами 1340-х годов (с изображением двуглавого орла), которые в 1350-х годах сменились еще более тяжелыми в среднем пулами (с изображением цветка-розетки), а им пришли на смену еще более тяжелые пулы Хызра и еще более тяжелые пулы второй половины 1360-х годов» [Федоров-Давыдов, 1987, c. 180].

Обнаруженные нами моды различных типов медных монет позволили скорректировать точку зрения Германа Алексеевича и установить, что:

1) пулы 1340-х гг. («двуглавый орел») не были тяжелее пулов 1330-х гг. («лев-солнце»), вес всех их стремился к одному и тому же значению веса;

2) по нашему представлению, полуторные пулы 1350-1360-х гг. не сменяли друг друга, а дополняли, насыщали рынки новыми номиналами;

3) после «тяжелых» пулов 768 г.х. в денежное обращение снова стали поступать монеты более легкие, с весом, стремящимся к значению в 2,1 г (фактически - 1,8-2,3 г) и 2,6 г;

4) по внешнему оформлению золотоордынских «медяков» можно говорить о весовой группе, к которой они принадлежали. Выявилась закономерность смена изображения на медной монете не всегда вела к смене весовой группы
- номинала, но смена номинала всегда вела к смене изображения (выделено автором - прим. ред.).

Кроме вышеназванных монетных дворов, на различных городищах и селищах XIV в. встречается продукция других монетных дворов - Булгара, Мохши, Хаджи-Тархана, Хорезма, Азака, Маджаpa, Орду, ал-Джадида, Крыма, Янгикента, Барчина, Дженда и анонимных монетных дворов. Например, по расчетам К. К. Хромова, весовые характеристики крымских пулов, чеканенных до 690 г.х., следующие: одни типы в диапазоне $1,1-$ 1,9 г с максимумами в пределах 1,3-1,6 г, второстепенные моды на гистограммах таких пулов имеют значение 2,3-2,6 г; другие типы - М6 и М7 - имеют максимумы 2,0-2,9 г со второстепенными модами на 3,8-4,4 г; тип М20 весит от 4,4 до 10 г (где М6 и т.п. - номера типов монет по классификации В. П. Лебедева ) [Хромов, 2017, с. 67-68; Лебедев, 2000]. По нашему мнению, медная чеканка МД Хорезм в XIV в. также могла быть представлена большим количеством номиналов. То есть, работа некоторых из монетных производств может быть названа относительно изученной, а работу других еще предстоит исследовать. Публикация и анализ метрологических и типологических особенностей серебряных и медных монет всех перечисленных монетных дворов помогут раскрыть состояние системы номиналов, обеспечивавших монетное медное обращение в Золотой Орде в XIII-XV вв.

Благодарность. Выражаю благодарность Павлу Николаевичу Петрову за ценные советы при написании данной статьи. 
Приложение 1

Гистограммы зависимости количества монет от значения их веса

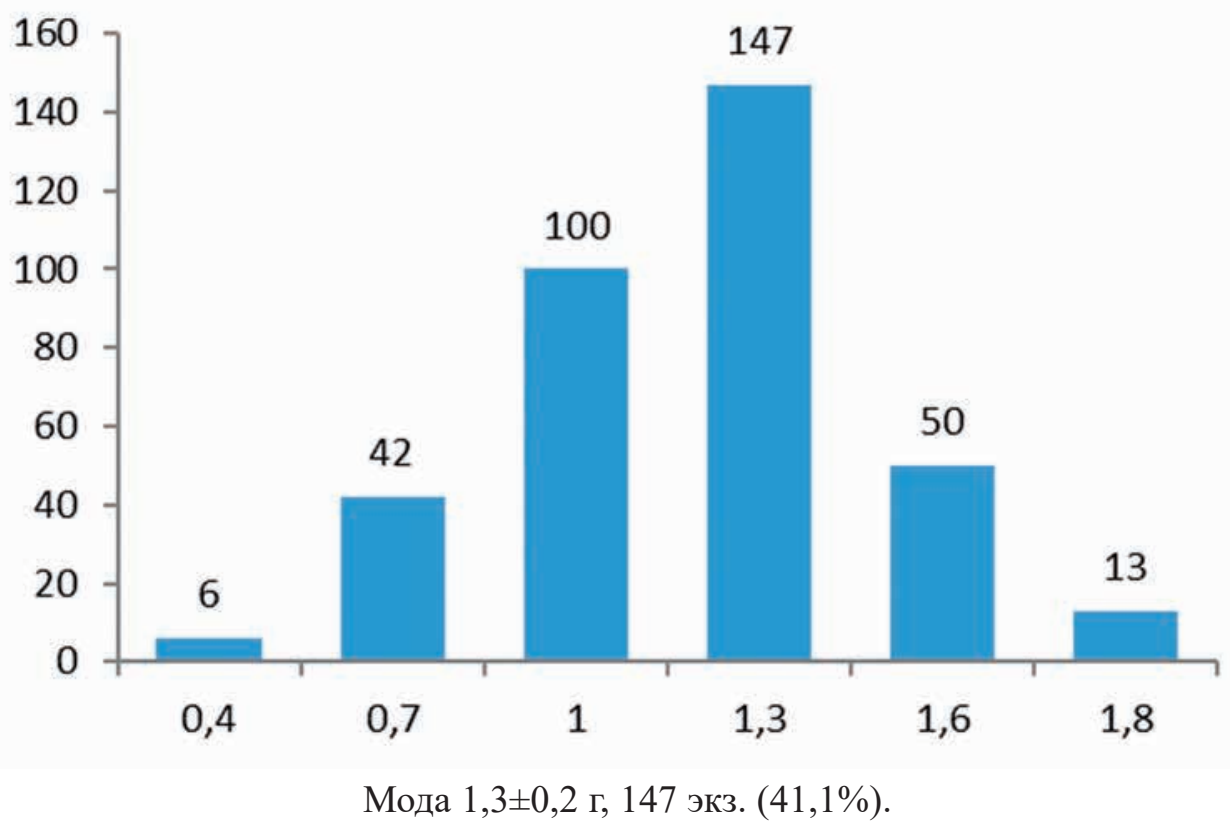

Гистограмма 1 - Зависимость количества пулов «двуглавый орел» от значения их веса. Учтено 358 экз. (по: [Клоков, Лебедев, 2002])

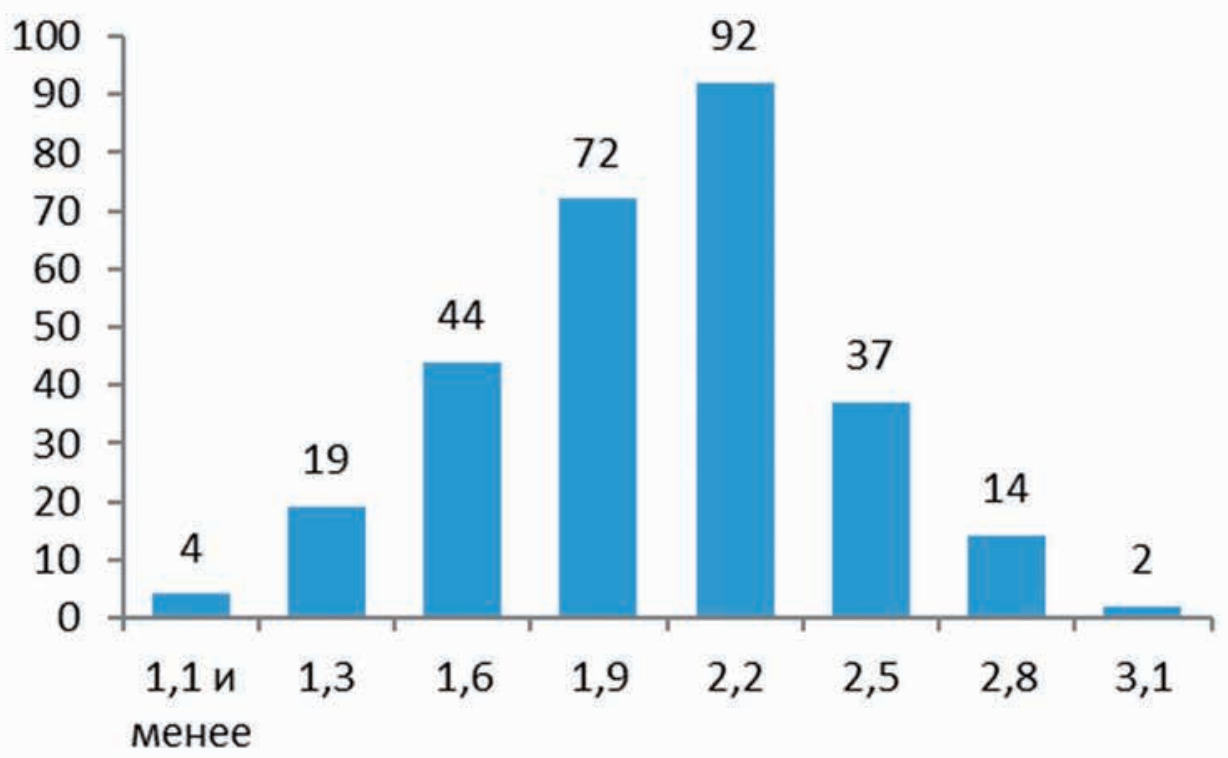

Мода 2,2士0,2 г, 92 экз. (32,4\%).

Гистограмма 2 - Зависимость количества пулов с «розеткой» (МД Сарай ал-Джадида) от значения их веса. Учтено 284 экз.

(по: [Клоков, Лебедев, 2002]) 


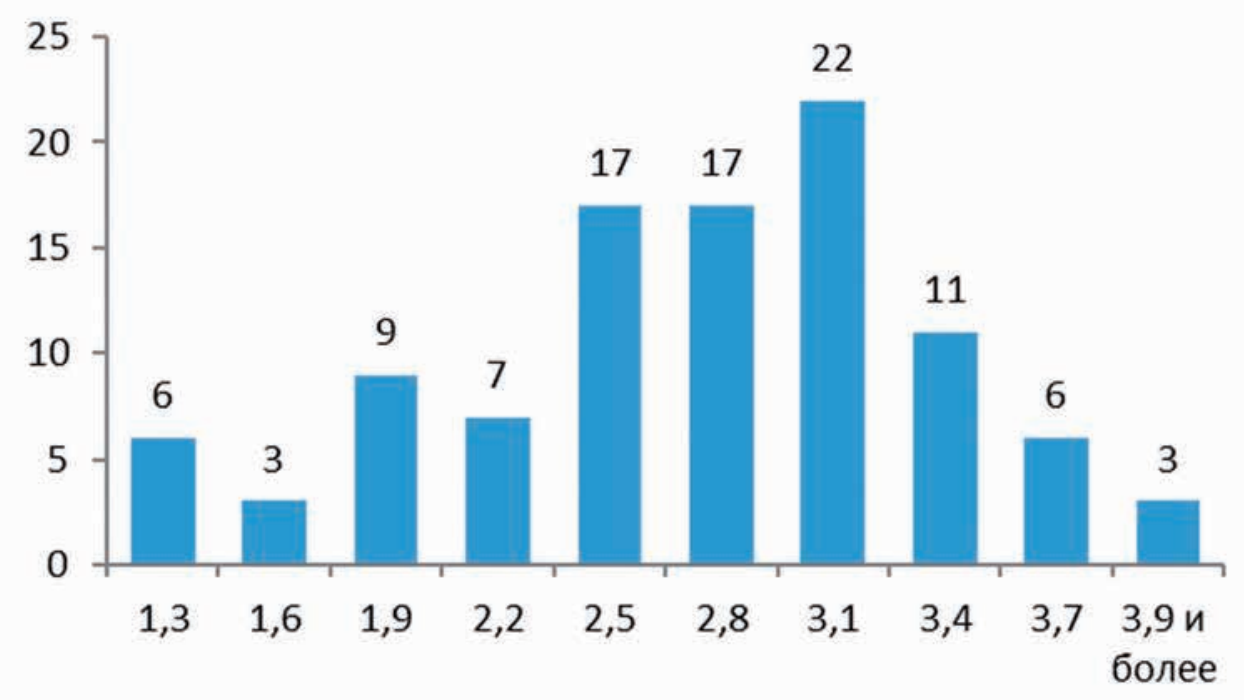

Мода 3,1士0,2 г, 22 экз. (21,8\%)

Гистограмма 3 - Зависимость количества пулов с именем Хызр-хана (МД Сарай ал-Джадид и Гулистан) от значения их веса. Учтен 101 экз. (по: [Клоков, Лебедев, 2002])

\section{ЛИТЕРАТУРА}

1. Виничек В.А., Лебедев В П. Период экономической активности на Никольском селище по нумизматическим данныи // Древности Поволжья и других регионов. Вып. V. Нумизматический сборник. T. 4. М.: Нумизматическая литература, 2004. C. $119-148$.

2. Гончаров Е.Ю. Медные монеты Сарая ал-Джадида // Древности Поволжья и других регионов. Вып. V. Нумизматический сборник. Т. 4. М.: Нумизматическая литература, 2004. С. 7-22.

3. Грибов Н.Н. Нижний Новгород в XV веке: поиски утраченного города. М.: ИА РАН, 2018. 589 с.

4. Давидович E.A. Денежное обращение в Мавераннахре при Саманидах // Нумизматика и эпиграфика. Т. VI. М.: Наука, 1966. С. 103-134.

5. Клоков В.Б., Лебедев В.П. Монетное обращение золотоордынского города Бельджамен // Древности Поволжья и других регионов. Вып. III. Нумизматический сборник. Т. 2. М.: ИПР «Информэлектро», 2000. С. 56-147.

6. Клоков В.Б., Лебедев В.П. Монетный комплекс с Селитренного городища (Золотая Орда, город Сарай) // Древности Поволжья и других регионов. Вып. IV. Нумизматический сборник. Т. 3. М.: Информэлектро, 2002. С. 73-165.

7. Клоков В.Б., Лебедев В.П. Монетные комплексы трех небольших золотоордынских поселений Нижнего Поволжья // Древности Поволжья и других регионов. Вып. V. Нумизматический сборник. Т. 4. М.: Нумизматическая литература, 2004. C. $76-118$.

8. Клоков В.Б., Лебедев В.П. Денежное обращение небольшой золотоордынской крепости в дельте Итиля (Чертово городище) // Татарская археология. 2004. № 1-2 (12-13). С. 73-85. 
9. Кротков А.А. Два собрания джучидских монет. Труды Нижневолжского общества краеведов. Вып. 37. Саратов: Издание Нижневолжского общества краеведения, 1930. 48 с.

10. Лебедев В.П. Корпус монет Крыма в составе Золотой Орды (сер. ХІІІ - нач. XV в.) // Вестник Одесского музея нумизматики. 2000. Вып. 2. С. 12-34.

11. Лебедев В., Клоков В. Монеты с юго-восточных окраин Сарая // Татарская археология. 2001. № 1-2 (8-9). С. 22-52.

12. Мухамадиев А.Г. Булгаро-татарская монетная система XII-XV вв. М.: Наука, 1983. 168 с.: XXI табл. ил.

13. Петров П.Н. Клад из Дев-кескен-кала и вопросы начала чеканки серебряных монет в Джучидском улусе // Золотоордынская цивилизация. 2010. Вып. 3. C. $121-149$.

14. Пигарев E.M. Золотоордынские монеты из раскопок и сборов археологической экспедиции музея-заповедника на Селитренном городище в 2003-2005 гг. (к общей статистике находок) // Монеты и денежное обращение в моногольских государствах XIII-XV веков: тр. Междунар. нумизм. конф. М.: Нумизм. литература, 2008. C. $128-136$.

15. Пигарев Е.M. Новые клады медных золотоордынских монет с Селитренного городища // Нумизматика Золотой Орды. 2014. № 4. С. 161-166.

16. Самашев 3., Бурнашева Р., Базылхан Н., Плахов В. Монеты Сарайчика. Алматы: Археология, 2006. 184 с.

17. Степанов О.В., Бугарчев А.И. Находки джучидских монет из окрестностей д. Сахаровка Алексеевского района РТ // Х Всероссийская научно-практическая историко-краеведческая (с международным участием) конференция «Проблемы истории и культуры Татарстана и народов Волго-Уральского региона». Вып. 6. Проблемы региональной истории и музейно-краеведческая работа. Казань: Изд-во «Яз», 2017. C. 29-32.

18. Федоров-Давыдов Г.А. Клады джучидских монет // Нумизматика и эпиграфика. 1960. Т. І. С. 94-192: 5 карт.

19. Федоров-Давыдов Г.А. Денежное дело Золотой Орды. М.: «Палеограф», 2003. 352 с. +40 с. ил.

20. Хромов К.К. Характеристика весовых данных крымских пулов, выпущенных до 690 г.х. // Девятнадцатая Всероссийская нумизматическая конференция: тезисы докл. и сообщ. (г. Москва, 18-22 апреля 2017 г.). М.: ГИМ; ИА РАН, 2017. С. 67-68.

21. Янина С.А. Джучидские монеты из раскопок и сборов Куйбышевской археологической экспедиции в Болгарах в 1946-1952 гг. // МИА СССР. 1954. № 42. С. 424 484.

22. Янина С.А. Джучидские монеты из раскопок и сборов Куйбышевской археологической экспедиции в Болгарах в 1953-1954 гг. // МИА СССР. 1958. № 61. С. 392423.

23. Янина С.А. Общий обзор коллекции джучидских монет из раскопок и сборов Куйбышевской археологической экспедиции в Болгарах (1946-1958 гг.) // МИА CCCP. 1962. № 111. С. 153-178.

24. Янина С.А. Монеты Золотой Орды из раскопок и сборов Поволжской археологической экспедиции на Царевском городище в 1959-1962 гг. // Поволжье в средние века. М.: Наука, 1970. С. 194-223: 4 табл. ил.

\section{Сведения об авторе:}

Бугарчев Алексей Игоревич - лаборант-исследователь, Институт археологии им. А.Х. Халикова АН РТ (г. Казань, Россия); Abugar.61@rambler.ru 


\section{XIV ғ. САРАЙДАҒЫ, ӘЛ-ЖАДИД САРАЙЫ МЕН ГУЛСТАНДАҒЫ БАҚЫР ТИЫНДАРДЫН МЕТРОЛОГИЯСЫ ТУРАЛЫ}

\section{А. И. Бугарчев}

Зерттеудің мақсаты XIV ғасырдағы Алтын Ордадағы бақыр тиындар жүйесінің кесімді құрылымын анықтау болып табылады. Ордалық бақыр тиындардың метрологиялық сипаттамасы қарастырылады. XIV ғ. түлі кезеңдерінде Сарайдағы, әлЖадид сарайы мен Гүлстанда жұмыс жасаған ақша сарайларының өнімдері зерттелді. Зерттеуге Водянское, Селитренное, Царевское, Зубовское, Колобовка и Чертово секілді қалашықтар мен елді мекендердерден жинақталған жинақтар пайдаланылды. Гистограмм түріндегі нәтижелерді пайдалана отырып, автор XIV ғ. бақыр тиындар түрлі кесімдерге сәйкес келетін әртүрлі салмақты топтармен соғылған деген қорытындыға келеді. Автордың пікірі бойынша XIV ғ. екінші жартысындағы ақша айналымында 1, $1 \frac{1}{2}, 2,2 \frac{1}{2}, 3,3 \frac{1}{2}$ және 4 пұлды бақырлар қолданылған. Олар тек салмағы жағынан ғана емес, сыртқы келбетімен де ерекшеленген, сонысына қарай тұрғындар оларды жеңіл ажырата алған.

Түйін сөздер: археология, Алтын Орда, Сарай, әл-Жадид сарайы, Гүлстан, XIV ғ., бақыр тиындар, пул, кешен, ақша сарайы

\section{ABOUT METROLOGY OF COPPER COINS OF SARAY, SARAY AL-JADID AND GULISTAN IN XIV CENTURY}

\section{A. I. Bugarchev}

In the article, the metrological characteristics of copper coins of the Golden Horde are considered. The author has studied the products of mints of Saray, Saray al-Jadid and Gulistan, which worked in different periods of the XIV century. For the study there were used the samples from such settlements as Vodyanskoe, Selitrenoe, Tsarevskoe, Zubovskoe, Kolobovka and Chertovo. Using the results in the form of histograms, the author concluded that copper coins of the XIV century were minted in different weight groups, which corresponds to different denominations. According to the author, in the monetary circulation of the second half of the XIV century coins were used in $1,1 \frac{1}{2}, 2,2 \frac{1}{2}, 3,3 \frac{1}{2}$ and 4 pūls. They were distinguished not only by weight, but also by appearance, so that they were easily identified by the population.

Keywords: archaeology, The Golden Horde, Saray, Saray al-Jadid, Gulistan, XIV century, copper coin, pūl, complex, mint

\section{REFERENCES}

1. Vinichek, V. A., Lebedev, V. P. 2004. In Petrov, P. N. (ed.) Numizmaticheskiy sbornik (Numismatic Proceedings), 4, 119-148 (in Russian).

2. Goncharov, E. Yu. 2004. In Petrov, P.N. (ed.) Numizmaticheskii sbornik (Numismatic Proceedings), 4, 7-22 (in Russian).

3. Gribov, N. N. 2018. Nizhnii Novgorod v XV veke: poiski utrachenogo goroda (Nizhniy Novgorod in $X V$ : search of the lost city). Moscow: Archeology Institute RAN Publ. (in Russian).

4. Davidovich, E. A. 1966. In Numizmatika i Epegrafika (Numismatics and Epegraphy), VI, 103-134 (in Russian).

5. Klokov, V. B., Lebedev, V. P. 2000. In P.N. Petrov, P. N. (ed.) Numizmaticheskii sbornik (Numismatic Proceedings), 2, 56-147 (in Russian).

6. Klokov, V. B., Lebedev, V. P. 2002. In Petrov, P. N. (ed.) Numizmaticheskii sbornik (Numismatic Proceedings), 3, 73-165 (in Russian). 
7. Klokov, V. B., Lebedev, V. P. 2004. In Petrov, P. N. (ed.) Numizmaticheskii sbornik (Numismatic Proceedings) 4, 76-118 (in Russian).

8. Klokov, V. B., Lebedev, V. P. 2004. In Tatarskaia Arkheologiia (Tatar Archeology), 1-2 (12-13), 73-85 (in Russian).

9. Krotkov, A. A. 1930. In Trudy Nizhnevolzhskogo obchestva kraevedov (Works of the Nizhnevolzhsky Society of Local History), 37 (in Russian).

10. Lebedev, V. P. 2000. In Vestnik Odesskogo muzeia numizmatiki (Bulletin of Odessa Museum of Numismatics) 2 (in Russian).

11. Lebedev, V. P., Klokov, V. B. 2001. In Tatarskaia Arkheologiia (Tatar Archeology), 1-2 (8-9), 22-52 (in Russian).

12. Mukhamadiev, A. G. 1983. Bulgaro-tatarskaya monetnaya sistema XII-XVvv. (Bulgar-Tatar monetary system of the 12th-15th centuries.). Moscow: "Nauka" Publ. (in Russian).

13. Petrov, P. N. 2010. In Zolotoordynskaia civilizaciia (Golden Horde Civilization), 3, 121-149 (in Russian).

14. Pigarev, E. M. 2008. In Petrov, P. N. (ed.) Trudy Mezhdunarodnikh numizmaticheskikh konferencii (Works of the International Numismatic Conferences). Moscow: "Numizmaticheskaia literatura" Publ., 128-136 (in Russian).

15. Pigarev, E. M. 2014. In Numizmatika Zolotoi Ordy (Golden Horde Numismatic), 4, 161-166 (in Russian).

16. Samashev, Z., Burnasheva, R., Bazylkhan, N., Plakhov, V. 2006. Monety Saraichika (Coins of Saraychik). Almaty: “Arkheologiya” Publ. (in Kazakh, Russian).

17. Stepanov, O. V., Bugarchev, A. I. 2017. In Burkhanov, A. A. (ed.) X Vserossiiskaya nauchno-practicheskaya (s mezhdunar. uchastiem) konferenciia (All-Russian scientific and practical historical and local history (with international participation), 6. Kazan: "Yaz" Publ., 29-32 (in Russian).

18. Fyodorov-Davydov, G. A. 1960. In Shelov, D. B. (ed.) Numizmatika i Epegrafika (Numismatic and Epegrafic), I, 94-192 (in Russian).

19. Fyodorov-Davydov, G. A. 2003. Denezhnoe delo Zolotoy Ordy (The Monetary Sistem of Golden Horde). Moscow: "Paleograf" Publ. (in Russian).

20. Khromov, K. K. 2017. In Deviatnadcataia Vserossiiskaia Numizmaticheskaia konferenciia (XIX All-Russian Numismatic Conference), 67-68 (in Russian).

21. Yanina, S. A. 1954. In Materialy i issledovaniia po arkheologii SSSR (Materials and Studies on the USSR Archaeology), 42, 424-484 (in Russian).

22. Yanina, S. A. 1958. In Materialy i issledovaniia po arkheologii SSSR (Materials and Studies on the USSR Archaeology), 61, 392-423 (in Russian).

23. Yanina, S. A. 1962. In Materialy i issledovaniia po arkheologii SSSR (Materials and Studies on the USSR Archaeology), 111, 151-178 (in Russian).

24. Yanina, S. A. 1970. In Povolzhie v srednie veka (Volga region in the Middle Ages), 194-223 (in Russian).

About the Author:

Bugarchev Alexey I. Laboratory researcher, Institute of Archaeology named after A.Kh. Khalikov, Tatarstan Academy of Sciences, Kazan; Abugar.61@rambler.ru

\footnotetext{
Мүдделер қақтығысы туралы ақпаратты ашу. Автор мүдделер қақтығысының жоқтығын мәлімдейді. / Раскрытие информации о конфликте интересов. Автор заявляет об отсутствии конфликта интересов.

/ Disclosure of conflict of interest information. The author claim no conflict of interest.

Мақала туралы ақпарат / Информация о статье / Information about the article.

Редакцияға түсті / Поступила в редакцию / Entered the editorial office: 04.11.2019.

Рецензенттер мақұлдаған / Одобрено рецензентами / Approved by reviewers: 11.11.2019.

Жариялауға қабылданды / Принята к публикации / Accepted for publication: 18.11.2019.
} 